Harmone Res. 1979;11:I-V

\title{
Contents, Vol. 11, 1979
}

\section{No. 1}

To Our Referees 1

Original Paper

Kim, K.S.; Morimoto, S.; Uchida, K.; Miyamori, I.; Miyamoto, M., and Takeda, R.:

Reduced Response of Plasma Aldosterone to Acute ACTH Stimulation during

Long-Term Treatment with Spironolactone in Essential Hypertension 4

Perez, CO.; Oster, J.R.; Katz, F.H., and Vaamonde, C.A.: The Effect of Acute

Metabolic Acidosis on Plasma Cortisol, Renin Activity and Aldosterone 12

Katznelson, D.; Sack, J.; Kraiem, Z., and Lunenfeld, B.: Congenital Hypoaldosteron-

ism. Thirteen Year Follow-Up in Identical Twins 22

Locard, E.; David, L.; Ruitton, A.; Chabanolle, F. de, and Francois, R.: Studies of

Growth Hormone Secretion in Juvenile Diabetes 29

Bagli, N.P.; Rajendran, K.G., and Shah, P.N.: Studies on the Mode of Action of

GonadotrophinTnhibiting Material (Anti-LH) Isolated from Human Urine .... 41

Book Reviews

49

Varia 52

No. 2

Original Paper

Healy, D.L.; Burger, H.G.; Korman, M.G., and Stern, A.: Long-Term Cimetidine Does

Not Alter Serum Prolactin 53

Peppier, R.D. and Stone, S.C: Effect of Oral Contraceptive Used by Technician on

Sensitivity of Progesterone Radioimmunoassay 56

Contents

IV

Roy, S. and Datta, J.K.: Counteraction of Testosterone-Induced Suppression of the Pituitary-Ovarian Axis in Rats by Flutamide 61

Lacroix, E. and Eechaute, W.: Estradiol Metabolism by Liver Homogenates and

Microsomes of Normal and Cirrhotic Male Rats 69

Dunbar, J.C.; Walsh, M.F., and Foà, P.P.: Secretion of Glucagon and Insulin in

Hypophysectomized Rats: Effect of Tolbutamide 81

Pollardo, L.F.; Gonzalez, C, and Jolín, T.: Diurnal Variations of Fecal and Urinary

Iodine Excretion in Rats 92

Taché, Y.; Du Ruisseau, P.; Ducharme, J.R., and Collu, R.: Adenohypophyseal

Hormone Response to Chronic Stress in Dexamethasone-Treated Rats 101

No. 3

Original Paper

D’Agata, R.; Gulizia, S.; Vicari, E.; Aliffi, A., and Polosa, P.: Effect of Cyproterone

Acetate Acutely Administered on the Pituitary-Testicular Axis 109 
Turpen, C. and Knigge, K.M.: Characterization of an in vitro Method for Demon strating Thyrotropin-Releasing Hormone-Stimulated Prolactin Secretion 115 Turpen, C. and Knigge, K.M.: In vitro Release of Prolactin by Thyrotropin-Releasing Hormone: Influence of Dopamine, Thyroxine, and Cyclohexamide 128

Goltermann, N. and Nandi Majumdar, A.P.: Stimulation of Gastric Mucosal Protein Synthesis by Different Molecular Forms of Gastrin 142

Benker, G.; Sandmann, K.; Tharandt, L.; Hackenberg, K., and Reinwein, D.: Gel Filtration Studies of Serum Growth Hormone in Acromegaly following Bromocriptine Administration 151

No. 4

Original Paper

Tamagna, E.I.; Lane, W.; Hershman, J.M.; Carlson, H.E.; Sturdevant, R.A.L.; Poland, R.E., and Rubin, R.T.: Effect of Chronic Metoclopramide Therapy on Serum Pituitary Hormone Concentrations 161

Feldman, J.M.; Blalock, J.A., and Zern, R.T.: Elevated Hypothalamic Norepinephrine Content in Mice with the Hereditary Obese-Hyperglycemic Syndrome 170

Thompson, E.A. jr. and Süteri, P.K.: Subcellular Distribution of Aromatase in Human Placenta and Ovary 179

Buul-Offers, S. van and Van den Brande, J.L.: Binding of Somatomedin-A and C, NSILA-S and Insulin to Human Placental Cell Membranes 186

Kannan, V.; Nabarro, J.D.N., and Cotton, P.B.: Glucagon Secretion in Chronic

Pancreatitis 203

Varia 212

Contents

$\mathrm{V}$

No. 5

Original Paper

Vermes, I.; Kajtár, I., and Szabó, E.: Changes of Maternal and Fetal Pituitary-Adrenocortical Functions during Human Labour 213

Blum, I.; Pertzelan, A.; Zadik, Z.; Prager-Lewin, R.; Assa, S., and Laron, Z.: Effect of Triiodothyronine Administration on the Plasma TSH and Prolactin Responses to TRH in Patients with Hypothalamic-Pituitary Insufficiency 218

Zucchelli, G.C.; Giannessi, D.; Piro, M.A.; Ferdeghini, M., and Malvano, R.: Radioimmunoassay of Unconjugated and Total Serum Estetrol Using a 125I-Iodinated

Tracer 227

Lea, O.A.: Interaction of Steroid-Binding Serum Proteins with Concanavalin

A-Sepharose 4B 240

Muniesa, A.; Llobera, M., and Herrera, E.: Adipose Tissue Cellularity in Hypo- and Hyperthyroids Rats 254

Masielo, P.; De Paoli, A.A., and Bergamini, E.: Influence of Age on the Sensitivity of the Rat to Streptozotocin 262

Book Review 275

Varia 276

No. 6

Heinz Karger Memorial Foundation Competition

Tobian, L.: Evidence for Na-Retaining Humoral Agents and Vasoconstrictor Humoral 
Agents in Hypertension Prone Dahl 'S' Rats 277

Original Paper

Zachmann, M.; Forest, M.G., and De Peretti, E.: 30-Hydroxysteroid Dehydrogenase

Deficiency. Follow-Up Study in a Girl with Pubertal Bone Age 292

Sandow, J.; Rechenberg, W. v.; Kuhl, H.; Baumann, R.; Krauss, B.; Jerzabek, G., and

Kille, S.: Inhibitory Control of the Pituitary LH Secretion by LH-RH in Male Rats 303

Waaler, P.E. and Aksnes, L.: Urinary Adenosine 3'5'-Monophosphate (Cyclic AMP) in

Normal and Cryptorchid Boys

318

Mattheij, J.A.M.; Gruisen, E.F.M., and Swarts, J.J.M.: The Suckling-Induced Rise of

Plasma Prolactin in Lactating Rats: Its Dependance on Stage of Lactation and

Litter Size 325

Letter to the Editor 337

Author Index 339

Subject Index 341 